Updating Article

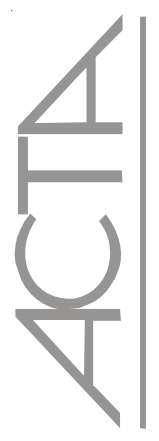

\title{
Malnutrition as a risk factor for the development of pressure ulcers
}

\author{
Desnutrição como fator de risco para o desenvolvimento de úlceras por pressão
}

Desnutrición como factor de riesgo para el desarrollo de las úlceras por presión

\author{
Letícia Faria Serpa ${ }^{1}$, Vera Lúcia Conceição de Gouveia Santos ${ }^{2}$
}

\begin{abstract}
Malnutrition - as a fundamental aspect both in genesis as in healing of pressure ulcers - is the object of this update paper. Countless studies point out that malnutrition, immune function alterations, hypoalbuminemia, low hemoglobin levels, as well as low diet intake, as responsible for an increase in the risk of developing these lesions. Therefore, it is essential to include the assessment of the nutrition status - monitoring of the calorie-protein intake and the difficulties to use the nutrients - in the prevention and treatment protocols of this type of chronic wound.
\end{abstract}

Keywords: Malnutrition; Pressure ulcer; Risk factors; Nutrition assessment

\section{RESUMO}

Resumo: A desnutrição - como aspecto fundamental tanto na gênese como na cicatrização das úlceras por pressão - é objeto deste artigo de atualização. Inúmeros estudos salientam a desnutrição, alterações da função imune, hipoalbuminemia, níveis baixos de hemoglobina bem como a baixa aceitação dietética como responsáveis por aumentar o risco para o desenvolvimento dessas lesões. É, portanto, fundamental incluir a avaliação do estado nutricional - monitorização da ingestão calórico-protéica e das dificuldades para o aproveitamento dos nutrientes - nos protocolos de prevenção e tratamento desse tipo de ferida crônica.

Descritores: Desnutrição; Úlcera de pressão; Fatores de risco; Avaliação nutricional

\section{RESUMEN}

La desnutrición - como aspecto fundamental en la génesis y cicatrización de las úlceras por presión (UP) - es el tema de esta atualización. Muchos estudios destacan la desnutrición, los cambios del funcionamiento imunológico, la hipoalbuminemia, los bajos niveles de hemoglobina así como la baja aceptación alimentaria como los responsables del aumento del riesgo para el desarrollo de las UP. En conclusión, es fundamental incluir la evaluación del estado nutricional en los protocolos de prevención y tratamiento de las UP. Esa evaluación debe incluir medidas objetivas, seguimiento de la ingestión calórica y protéica y además de las dificultades para el aprovechamiento de los nutrientes.

Descriptores: Desnutrición; Úlceras por presión; Factores de riesgo; Evaluación nutricional

\footnotetext{
${ }^{1}$ Ph.D. in Adult Health at Escola de Enfermagem da Universidade de São Paulo, Nurse at Hospital Alemão Oswaldo Cruz - São Paulo, (SP), Brazil.

2 Stomatherapist Nurse (TiSOBEST), Associate Professor at the Department of Medical-Surgical Nursing of the Escola de Enfermagem da Universidade de São Paulo - USP - São Paulo,(SP), Brazil.
} 


\section{INTRODUCTION}

Pressure ulcers (PU) still pose important challenges for the health professionals. A lot has been discussed about causality, physiopathogeny and prevention and treatment strategies focused mainly on higher risk populations, such as patients with critical and chronic diseases, as well as the elderly ${ }^{(1)}$. Some studies have shown prevalence of up to $66 \%$ in intensive therapy units $^{(2-3)}$. Souza ${ }^{(4)}$ shows UP cumulative incidence of $39.4 \%$, in institutionalized elderly.

Several scales to assess the risk of PU development are available. The most popular are Braden and Waterlow, both validated for the Brazilian population. Braden scale was developed by Bergstrom and colleagues, in 1987, as a means to optimize prevention strategies and, thus, decrease the incidence of this type of ulcer ${ }^{(5)}$. These authors established a conceptual framework for the study of UP etiology, involving the two critical determinants: intensity and pressure duration and skin tolerance and underlying structures to support it. Nutrition composes one of the subscales of Braden scale - related to tissue tolerance - and is designed to assess nutrient intake ${ }^{(5)}$. Waterlow's scale was developed by Waterlow, in 1985, and includes a higher number of variables, among them, the nutritional status translated by the assessment of the Body Mass Index (BMI) and appetite, besides some skin characteristics ${ }^{(6)}$.

Considering nutrition as an essential factor in the PU etiopathogeny, this bibliographic update aimed at analyzing some nutritional aspects that interfere in the development and healing of these lesions and also suggesting some procedures, in nursing, that may attenuate these alterations.

\section{MALNUTRITION AND PRESSURE ULCERS}

The severe protein-calorie malnutrition alters tissue regeneration, inflammatory reaction and the immune function $^{(7)}$, making individuals more vulnerable to the UP development ${ }^{(1,8-9)}$. In the elderly, the low level of serum albumin may be considered as an evidence of protein malnutrition and hypercatabolism ${ }^{(4,10)}$.

Here are the main nutritional indicators and the studies related to the PU development.

Body weight - as important component of nutritional indicators - has been regarded as a factor related to the development and severity of $\mathrm{PU}^{(3,11)}$. Thinning reduces the layer of thick fat, and consequently, reduces protection against pressure. Fife $^{(3)}$ suggests aggressive preventive measures in patients with Braden score $\leq 13$ and low BMI, at admission.

Anemia may contribute to PU formation and diminish the amount of oxygen for the fibroblasts and, thus, it reduces the formation of collagen and increases tissue susceptibility to the development of this and other types of lesions ${ }^{(12)}$.

Furthermore, reduced protein-calorie intake may predict the development of PU. Some causes of this diminishing are the constant lack of appetite and food restriction imposed by the treatment ${ }^{(8)}$. For the elderly, the causes are the need of help to eat, cognitive and communication impairment, the use of medication that interfere in appetite and increase the nutrient loss and psychosocial factors, such as isolation and depression ${ }^{(8)}$. Patients who receive higher protein-energy intake, and specific nutrients, tended to develop less PU and showed better healing ${ }^{(13-14)}$. More recent studies point out the importance of some nutrients in each step of the healing process: inflammatory, proliferative and remodeling ${ }^{(14-15)}$. In a systematic and metanalysis review, it was seen that nutritional therapy, particularly oral nutritional supplementation with high protein value, may significantly diminish the risk of PU development ${ }^{(9)}$. Houwing and colleagues $^{(13)}$ verified that patients who had received diet supplement enriched with protein, arginine, zinc and antioxidants showed lower PU rates in stage II, when compared with the control group. In another study, the specific oral nutritional supplementation resulted in a significant reduction in the wound area and improved the PU conditions in stages III and IV ${ }^{(16)}$. In patients under stress, the nitrogen retention and the administration of micronutrients are prioritary for the PU healing ${ }^{(15)}$.

Among the PU prevention strategies are the skill of professionals in recognizing patients with risk of developing PU and assess the nutritional status ${ }^{(17)}$. They should value the protein-energy needs, individual preferences and hydration. In case of enteral or parenteral nutritional therapy, there should be a care protocol with the access via, nutrient administration and complication prevention.

Patients with movement restrictions and some level of dependency also need guidance and support measures of the team or family, mainly the elderly.

\section{CONCLUSIONS}

It can be stated that some variables have been regarded as risk predictors for the PU development. Hence, it is essential to have other assessment objective strategies of the nutritional status, which may be performed by the nurse, and incorporated to the risk assessment scales.

A recent study has shown that, nutritionally, albumin and global subjective nutritional assessment were the main predictive variables of risk of PU development ${ }^{(18)}$.

It is certainly essential to establish institutional prevention programs, which support the health 
multidisciplinary team interventions in order to control

\section{REFERENCES}

1. Donini LM, De Felice MR, Tagliaccica A, De Bernardini L, Cannella C. Nutritional status and evolution of pressure sores in geriatric patients. J Nutr Health Aging. 2005; 9(6): 446-54.

2. Rogenski NMB, Santos VLCG. Estudo sobre a prevalência de úlceras por pressão em um hospital universitário. Estima. 2006; 4(2):16-22.

3. Fife C, Otto G, Capsuto EG, Brandt K, Lyssy K, Murphy $\mathrm{K}$, Short $\mathrm{C}$. Incidence of pressure ulcers in a neurologic intensive care unit. Crit Care Med. 2001; 29(2):283- 90.

4. Souza DMST, Santos VLCG. Incidência de úlceras por pressão e fatores de risco em idosos institucionalizados. Estima. 2006; 4(1):45.

5. Bergstrom N, Braden BJ, Laguzza A, Holman V. The Braden Scale for Predicting Pressure Sore Risk. Nurs Res. 1987; 36(4):205-10.

6. Waterlow J. Pressure sores: a risk assessment card. Nurs Times. 1985; 81(48):49-55.

7. Young ME. Malnutrition and wound healing. Heart Lung.1988; 17(1):60-7. Review.

8. Harris CL, Fraser C. Malnutrition in the institutionalized elderly: the effects on wound healing. Ostomy Wound Manage. 2004; 50(10):54-63. Erratum in: Ostomy Wound Manage. 2004; 50(11):10.

9. Stratton RJ. Elucidating effective ways to identify and treat malnutrition. Proc Nutr Soc. 2005; 64(3):305-11.

10. Bours GJ, Halfens RJ, Abu-Saad HH, Grol, RT. Prevalence, prevention, and treatment of pressure ulcers: descriptive study in 89 institutions in the Netherlands. Res Nurs Health. 2002; 25(2):99-110. risk factors, including the nutritional parameters.

11. Bates-Jensen BM. Quality indicators for prevention and management of pressure ulcers in vulnerable elders. Ann Intern Med. 2001; 135(8 pt 2):744-51. Comment in: Ann Intern Med. 2002; 137(8):W2.

12. Russell L. Malnutrition and pressure ulcers: nutritional assessment tools. Br J Nurs. 2000; 9(4):194-6, 198, 200 passim.

13. Houwing RH, Rozendaal M, Wouters-Wesseling W, Beulens JW, Buskens E, Haalboom JR. A randomised, double-blind assessment of the effect of nutritional supplementation on the prevention of pressure ulcers in hip-fracture patients. Clin Nutr. 2003; 22(4):401-5.

14. Lee SK, Posthauer ME, Dorner B, Redovian V, Maloney MJ. Pressure ulcer healing with a concentrated, fortified, collagen protein hydrolysate supplement: a randomized controlled trial. Adv Skin Wound Care. 2006; 19(2): 92-6.

15. Mechanick JL. Practical aspects of nutritional support for wound-healing patients. Am J Surg. 2004; 188 (1A Suppl):52-6.

16. Frías Soriano L, Lage Vázquez MA, Maristany CP, Xandri Graupera JM, Wouters-Wesseling W, Wagenaar L. The effectiveness of oral nutritional supplementation in the healing of pressure ulcers. J Wound Care. 2004, 13(8):31922.

17. Thomas DR. Prevention and treatment of pressure ulcers. J Am Med Dir Assoc. 2006; 7(1):46-59.

18. Serpa LF. Capacidade preditiva da subescala Nutrição da Escala de Braden para avaliar o risco de desenvolvimento de úlceras por pressão [tese]. São Paulo: Escola de Enfermagem da Universidade de São Paulo; 2006. 